\title{
Estruturação da mercadoria das emissoras comerciais sob a convergência: apontamentos para uma economia política da indústria radiofônica'
}

The structuring of the merchandise of commercial broadcasting stations within a convergence: notes for a political economy of radio industries

\section{LUIZ ARTUR FERRARETTO}

Doutor em Comunicação e Informação pela Universidade Federal do Rio Grande do Sul (UFRGS). Professor do Programa de Pós-Graduação em Comunicação e Informação da Faculdade de Biblioteconomia e Comunicação da Universidade Federal do Rio Grande do Sul (UFRGS),

Porto Alegre, RS, Brasil.

<luiz.ferraretto@uol.com.br>

\section{RESUMO}

Com base na economia política da comunicação, este artigo identifica as alterações ocorridas, ao longo do tempo, na conformação da mercadoria oferecida pelas emissoras comerciais. Apoia-se na argumentação de Dallas Smythe (1983) a respeito da configuração da audiência como tal e na proposta de periodização da história do rádio brasileiro apresentada em trabalho anterior. Cotejando a proposição do pesquisador canadense com as alterações sofridas pelo meio e pelo sistema capitalista desde a década de 1970, oferece elementos para complementar aquela noção, a saber o papel da identidade

\section{ABSTRACT}

Based on the political economy of communication, this work attempts to define the alterations that have occurred throughout time, in the framework of the merchandise offered by commercial broadcasting stations. It is based on the arguments of Dallas Smythe (1983) in relation to the configuration of the audience as such, as well as on the proposal for the periodization of the history of Brazilian radio broadcasting presented in a previous paper (Ferraretto, 2012). This paper intends to offer elements to complement this notion, taking into account the proposition made by the Canadian researcher, with the alterations which have been caused by the environment 
da emissora e do relacionamento com a marca. Busca, deste modo, apresentar subsídios para a compreensão do negócio radiofônico na contemporaneidade, quando a convergência passa a predominar como estratégia mercadológica.

Palavras-chave: Rádio comercial. Mercadoria. Identidade. and by the capitalist system since the 70 s, that is, the role of the identity of broadcasting stations and the relation with the brand. In this way, the work allows for the comprehension of the radio broadcasting business in contemporaneity, when the convergence starts to predominate as a marketing strategy.

Keywords: Commercial radios. Merchandise. Identity.

Por que sintonizar uma rádio do segmento de jornalismo em determinado horário se 1 qualquer portal de notícias oferece, a todo momento, o mesmo tipo de conteúdo? Por que aguardar a transmissão das informações da previsão do tempo ou do trânsito se há aplicativos que fornecem estes dados a qualquer instante? Por que escutar agora uma entrevista ou outro tipo de conteúdo radiofônico se é possível ouvi-los em streaming ou em um podcast mais tarde? Por que sintonizar uma programação musical se suas músicas preferidas estão no celular, computador, MP3 player, tablet ou nos mais diversos dispositivos? Por que ouvir a narração de um jogo de futebol pelo rádio se a televisão oferece o mesmo conteúdo acrescido da imagem? São inquietações das últimas duas décadas, crescentes à medida que a euforia das então novas tecnologias de informação e comunicação oferecem gama significativa de alternativas em comparação à aparente pequenez do rádio, o mais antigo dos meios eletrônicos massivos. No entanto, as TICs introduzidas desde os anos 1990 não causaram a derrocada temida, a exemplo do que chegou a seprever, também, nos anos 1950 e 1960, em relação ao impacto provocado pela televisão.

Pode se responder ao conjunto destas questões de forma simples. O rádio não oferece apenas informação; fornece certo grau de emoção, de sentimento, de uma ideia 
de pertença e de proximidade;estabelece também relações entre a emissora, o comunicador e a audiência, dirigindo-se a todos os ouvintes como se falasse para cada um em particular. Fora isto, constitui-se no único meio de comunicação massivo que permite uma recepção razoavelmente completa e simultânea à realização de outras tarefas.

O rádio, desde o surgimento dos receptores transistorizados, acompanha o ouvinte. Se acompanha, torna-se, portanto, um companheiro no cotidiano. E carrega esta capacidade ao se mimetizar com os aparelhos de telefonia móvel. Tende, ainda, a ser um meio predominantemente regional. Mesmo quando opera em cadeia, abremse janelas para o conteúdo local e, deste modo, mostra-se ainda mais próximo. Em resumo, fator fundamental para a reflexão aqui encetada, constitui-se na primeira rede social mediada pela tecnologia eletrônica da história da humanidade.

Tal caracterização passa necessariamente pelo que, neste artigo, aparece rotulado como "identidade da emissora", expressão que remete tanto ao que os gestores, em seu afã comercial, denominam de marca, quanto à relação a ser estabelecida entre a rádio e seu público, o qual, para fazer parte desta espécie de comunidade imaginária que se desenvolve em torno da estação, de seus profissionais e de seus programas, precisa também necessariamente se identificar com esses elementos a conformarem a feição de uma emissora em particular. Neste sentido, com base na economia política da comunicação, propõe-se uma reflexão a respeito das relações estabelecidas entre empresa, público e anunciantes.

Antes, faz-se necessária breve recuperação histórica, buscando demarcar a transição das emissoras comerciais ao patamar de um ramo econômico específico dentro das indústrias culturais, dedicado à obtenção de lucro pela operação comercial de outorgas de rádio. Há, aqui, uma distinção conceitual entre o negócio radiofônico, expressão mais abrangente, e a radiodifusão sonora, considerada como indústria cultural. Por exemplo, embora constituído como o principal meio de comunicação ao longo dos anos 1940 e 
1950, quando predominou a programação baseada no espetáculo dos humorísticos, novelas e programas de auditório, o rádio não chegou a se conformar, na época, como indústria cultural na referência às formulações teóricas de Theodor WiesengrundAdorno e Max Horhkeimer. Atenta-se, deste modo, para a advertência de Ortiz (1994, p. 48) a esse respeito.

Como em outros ramos da produção cultural, a passagem do negócio radiofônico ao seu estágio de indústria cultural está relacionada ao advento da sociedade de consumo, que coincide com o chamado "Milagre Brasileiro", denominação ufanista cunhada pela ditadura militar, instaurada em 1964, para o período de crescimento econômico, registrado entre 1967 e 1973. Desde então, vão estar presentes características como: (a) a audiência massiva, tratada como objeto da indústria cultural - "um elemento de cálculo", na expressão de Adorno (1978, p. 288) -, e não como seu sujeito; (b) a assimilação de formas industriais de organização do trabalho e de racionalização da produção; (c) o incentivo à estruturação de um sistema de vedetes, baseado na divulgação de personalidades supostamente importantes - "tipos ideais da nova classe média", na definição de Adorno e Horkheimer (1986, p. 136) -, dando um caráter de aparente individualização ao que, de fato, se apresenta genérico e homogeneizado; e (d) a orientação do conteúdo por uma motivação comercial em que a lógica do lucro suplanta a da arte, situação, obviamente, comum ao rádio como negócio, mas levada, em sua fase industrial, a requintes de planejamento e/ou à exploração máxima dos recursos disponíveis, sejam os de ordem material ou os relacionados à mão de obra.

Há que considerar ainda a forma como este conceito geral para toda a comunicação massiva aparece reinterpretado pela economia política da comunicação, admitindo-se uma transição ao plural da ideia frankfurtiana de indústria cultural e demonstrando, desta maneira, uma diversidade de estruturas particulares desenvolvidas pelo capital. Como observam Armand e Michèle Mattelart (1997, p. 77), “trata-se de entrar na 
complexidade destas diversas indústrias para tentar compreender o processo crescente de valorização das atividades culturais pelo capital". Toma-se, portanto, o rádio como um ramo específico de investimento e geração de lucro dotado de lógicas próprias.

Na história do rádio brasileiro, após uma fase de (1) implantação, marcada pelo associativismo idealista de elite, ou seja, por entidades a reunirem integrantes da burguesia com o objetivo de divulgação de uma cultura amparada nos valores dominantes dessa parcela da população, identifica-se a existência de mais três períodos.

A partir da regulamentação da publicidade radiofônica, em 1932, e, portanto, já sob a hegemonia do rádio comercial, são, a saber: as fases de (2) difusão, do início da década de 1930 até a segunda metade dos anos 1960; (3) segmentação, do final da década de 1950 até o início do século 21; e (4) convergência, de meados da década de 1990 até a atualidade.

Na delimitação dessas, consideram-se como marcos a introdução de novos meios, suportes e/ou tecnologias de comunicação: (1) a televisão aberta, o receptor transistorizado e a frequência modulada; e (2) a telefonia móvel, a internet e tecnologias derivadas. Tais elementos orientam a passagem de uma para outra estratégia mercadológica.

De Richers (1991, p. 15) vêm as definições de difusão - "espalhar os produtos pelo mercado afora, sem se preocupar com quaisquer diferenças que possam existir entre os compradores em potencial" - e de segmentação - "a demanda não é uniforme, mas sim heterogênea, o que justifica uma concentração dos esforços de marketing em determinadas fatias específicas do mercado". Por sua vez, o termo convergência expressa a consciência em nível empresarial da aproximação entre comunicação de massa, informática e telecomunicações, corporificada, no caso do rádio comercial, na disponibilização de conteúdo radiofônico para além das ondas eletromagnéticas (Ferraretto; Kischinhevsky, 2010).

Cabe observar que os dados históricos indicam alterações no modo como as emissoras consideram a mercadoria oferecida pelo rádio. De início, o negócio 
comunicacional representado por uma estação procura vender a programação associada à imprecisa ideia de seu impacto, uma vez que as pesquisas de audiência só ganham força e se generalizam na década de 1970. Com o público quantificado com maior exatidão, é esse número ou percentual de ouvintes com suas características de potencial de consumo que passa a ser comercializada junto aos anunciantes. Sob a vigência do capitalismo monopólico e com a convergência, gradativamente, assumindo papel protagônico, conteúdo e público associam-se, mais e mais, à noção de identidade ou de marca da emissora e/ou do conglomerado ao qual a rádio está ligada.

Em termos de suportes, é importante também explicitar a gama de manifestações que, para além do hertziano, o radiofônico passa a englobar em sua fase de convergência: (1) rádio na web², adotada para a prática das emissoras hertzianas de disponibilizarem o seu áudio em streaming ou em arquivos para podcasting na rede mundial de computadores; (2) web rádio, que identifica a emissora constituída para a transmissão exclusiva ou preponderantemente via internet; e (3) rádio on-line, o conjunto que engloba as duas categorias anteriores. Assumem-se, portanto, como radiofônicos também o podcast sonoro e as web rádios, desde que seus conteúdos sejam produzidos dentro dos parâmetros de uma linguagem específica.

Neste sentido e em outros que surgirem, configura-se, na oportuna expressão de Kischinhevsky (2012, p. 431), o rádio expandido, que não se restringe ao hertziano e o qual, nesta nova conformação e sob o ponto de vista das emissoras comerciais, busca alternativas em termos de exploração capitalista.

\section{A comunidade de ouvintes ${ }^{3}$}

Ao ascender ao posto de figura central da programação de rádio, o comunicador simula um contato pessoal mesmo que, em realidade, se trate de um processo a distância, mediado pela tecnologia de transmissão empregada na conexão da emissora 
com o ouvinte. Na situação comum desde a década de 1970, à medida que a utilização do telefone se dissemina ainda em sua forma fixa, o ouvinte pode ligar para uma estação de rádio e interagir com aquele profissional de microfone. Ao fazê-lo, no plano do imaginário dos que os escutam, conversa também com o restante desta audiência. Pelo papel que assume de companheiro cotidiano, o comunicador, graças à portabilidade do receptor transistorizado, acompanha o seu público, criando uma espécie de comunidade virtual neste entorno medido pelo alcance das estações e, hoje, em função da internet, não restrito exclusivamente ao hertziano. Essa situação, de certo modo, mascara outro processo, aquele relacionado ao fato de que uma emissora de rádio, no modelo predominante no caso brasileiro, configura-se como empresa e, sendo assim, busca faturamento, o qual, custos à parte, tem parcela sua transformada em lucro dentro do processo de acumulação capitalista. Para entender este duplo processo, busca-se amparo, embora estes possam ser considerados de outra linha sociológica, nos escritos de Tönnies (In: Miranda, 1995), a respeito do processo de formação de comunidades e sociedades, e de Meyrowitz (1989), no que se relaciona às novas formas de associação provocadas pelos meios de comunicação eletrônicos. Este aporte é consideravelmente válido para a compreensão dos laços que unem a audiência a uma emissora, profissional ou programa determinado.

Baseando-se nos fundamentos psíquicos da ação humana, o sociólogo alemão diferencia uma vontade "entendida como real e natural", a que chama de (1) wesenville - traduzida no Brasil como orgânica, essencial ou natural - da "compreendida como ideal ou artificial", denominada (2) kürville - frequentemente identificada como mecânica, reflexa ou natural (Tönnies, in: Miranda, 1995, p. 273). A primeira compreende o (a) desejo, relacionado à atividade vegetativa e ligado, portanto, a necessidades fisiológicas; o (b) hábito, resultante da experiência, o exercício prático interiorizado; e a (c) memória, que envolve a capacidade de reproduzir atos com finalidades específicas. A segunda, 
por sua vez, apresenta-se sob três formas: a (a) reflexão, que baseia uma determinada ação intencional; a (b) conveniência, a determinar se as consequências de um ato, ou seja, se esse é positivo ou não para aquele agente em particular; e o (c) conceito, um juízo associativo em um contexto determinado que permite ao sujeito construir o seu discurso.

Quando nas relações sociais predomina a wesenville, origina-se o que Tönnies chama de (1) gemeinschaft - em português, comunidade. Quando se sobrepõe a kürville, organizase o que o autor denomina de (2) gesellschaft - a sociedade -, onde "cada um está por si e isolado, e em um estado de tensão perante todos os outros"' (Tönnies In: Miranda, 1995, p. 252). Essa última caracteriza-sepor transações e trocas envolvendo a noção de valor e, deste modo, um ajuste de interesses entre as partes. Já a gemeinschaft, por origem, menos reflexiva, manifesta-se na forma de três gêneros: o (a) parentesco, baseado em laços sanguíneos; a (b) vizinhança, na qual os indivíduos têm em comum a proximidade entre os lugares onde convivem; e a (c) amizade, pela semelhança entre as condições de trabalho ou modo de pensar (Tönnies In: Miranda, 1995, p. 248-9).

$\mathrm{Na}$ compreensão das ideias associadas a estas palavras, recorre-se ao filólogo Antenor Nascentes (1981), autor do principal dicionário de sinônimos produzido no Brasil. Para a comunidade de ouvintes, a noção de parentesco, na sua acepção mais direta, pode ser abandonada. No entanto, como registra Nascentes (1981, p. 196), expressões como "contraparente" ou "parente afim" remetem à afinidade entre os que não possuem laços sanguíneos.

Há também a noção de familiaridade, "modo de tratar um estranho, como se fosse pessoa da família" (Nascentes, 1981, p. 153). Já amizade, o ato de ter amigos, remete ao "apego recíproco entre duas pessoas que se estimam" (Nascentes, 1981, p. 43), enquanto vizinho representa "o que não está afastado, o que está mais perto" (Nascentes, 1981, p. 37). Fora deste paralelo com as teorizações de Tönnies, salientase a necessidade de destacar o que o senso comum dicionarizado atribui como 
significado à palavra companheiro: "o que anda na mesma companhia que outro ou outros" (Nascentes, 1981, p. 153).

Advoga-se que o rádio, ao diminuir distâncias, rompe com a noção de espaço e atrai, pela identidade apresentada pela emissora e pela portabilidade do aparelho receptor, os ouvintes, talvez não por uma ideia de comunidade baseada em quem se relaciona com um parente, um vizinho ou um amigo, mas, com menor risco de erro nesta assertiva, amparada em simulacros destas interações.

No processo iniciado pelos radinhos de pilha e autorrádios, e mantido pelos dispositivos móveis - em especial, o telefone celular -, o meio assume, como referido anteriormente, o papel de companheiro. Facilitam isso o caráter eminentemente regional das irradiações e a possibilidade de as informações serem recebidas em paralelo à realização de atividades cotidianas. Articula-se, talvez não na acepção dada à expressão em tempos de internet, uma espécie de rede social em torno dos comunicadores.

Usando como base os escritos de Adorno e Horkheimer (1986, p. 136), pode-se dizer que tais profissionais configuram-se em vedetes e símbolos de referência para os ouvintes. No conjunto, trata-se da experiência social descrita por Meyrowitz (1989) e comum a meios como o rádio, que desenvolvem formas de acesso e associação pouco relacionadas com a localização física dos seus integrantes. Esta perspectiva é resumida pelo professor da Universidade de New Hampshire na frase: “Os meios eletrônicos movem as pessoas, de modo informacional, para o mesmo lugar" (Meyrowitz, 1989, p. 145). No seu entender, os meios eletrônicos são agentes criadores de uma nova comunidade, unida por outros laços que não os físicos: os de compartilhamento de informações e experiências.

Especificamente a respeito do rádio, Bruck (2003, p. 30) destaca, baseando-se em Vanessa Paiva (1995), o elevado poder de sociabilidade do meio, ou seja, a rede de relações construídas em torno do compartilhamento de experiências entre a emissora 
e os seus ouvintes. Sem adentrar as questões específicas à sociabilidade e à recepção, apropriadamente colocados pelo autor, mas fora do escopo deste artigo, é importante considerar, como, com prudência, faz o pesquisador da Pontifícia Universidade Católica de Minas Gerais, que seria um exagero atribuir à escuta radiofônica significação idêntica ao ato de se relacionar socialmente de modo presencial (Bruck, 2003, p. 35). Tal ressalva, no entanto, não implica na inexistência de certo grau deste:

[...] não é exagero dizer que 'ouvir rádio' reveste-se de um caráter de ação social. A audiência radiofônica significa abrir-se ao entretenimento a partir de uma opção esteticamente determinada. É, porém, ao mesmo tempo, dispor-se ao mundo que o rádio constrói com seus debates públicos, conceitos, preconceitos, julgamentos, imaginários, afetividades e rejeições, que saltam para a vida do público, transportados pela voz que magnetiza o ouvinte, criando para ele uma sensação de presentificação dos ambientes e situações ofertados e de uma proximidade, uma identificação com todo o universo proposto pela emissora. Firmando a audiência radiofônica como um hábito e transformando essa audiência em uma ponte para o 'mundo lá fora' [...], o ouvinte envolve-se em um diverso modo de socialização. Por ser ouvinte, ele experimenta, relacionase e inscreve-se em grupos que se fundam a partir, exclusivamente, dessa audiência. Se já não é mais a praça pública, a posição no dial e o horário do programa passaram a ser as referências de tempo e espaço para esses grupos. Isso lhes garante a comunhão nos debates desenvolvidos, nos conceitos e preconceitos disseminados, nas afetividades ou rejeições distribuídas. É um compartilhamento de experiências que passam pelo entendimento e pelo afeto."

(Bruck, 2003, p. 40) 
Bruck (2003)ampara-se, ainda, nas formulações do semiólogo argentino Eliseo Verón a respeito dos contratos de leitura, observando:

Os contratos revelam a opção do receptor não apenas por um modo de se mostrar o mundo, mas denotam definições a partir de identificações e representações que se estabelecem a partir do político e do ideológico, da ética e da moral. O estético e o psicológico."

(Bruck, 2003, p. 40)

A utilização de tais formulações, mesmo que fora do âmbito da economia política da comunicação e, em outras particularidades, até divergentes em relação a este, auxiliam na compreensão desta comunidade virtual. $\mathrm{O}$ recurso a elas, sem recorrer a estudos de recepção, permite relativa compreensão a respeito do público e de seu comportamento. Falta, no entanto, adentrar um pouco o terreno da outra parte deste contrato entre emissor e receptor: o dos radiodifusores.

Neste sentido, deve-seanalisar proposições que ressaltam a necessidade do meio empresarial valorizar a fidelização do cliente (Prata, 2003) e a promoção e venda de relacionamentos (Morgado, 29 mar. 2011/27 set. 2011). A primeira, de cunho científico, ampara-se em estudo de recepção com ouvintes da Rádio Itatiaia, de Belo Horizonte, originalmente a dissertação de mestrado ${ }^{4}$ de Nair Prata (2000), enquanto a segunda constitui-se em uma descrição de Fernando Morgado, consultor de empresas do setor, a respeito da realidade das emissoras de rádio sob a vigência da internet.

Embora saliente as dificuldades para definir o que seria um ouvinte fiel, algo que "vai variar de acordo com cada emissora que consegue manter a audiência exclusiva 
por motivos específicos" (Prata, 2013, p. 139), a pesquisadora mineira apresenta algumas pistas:

[...] o ouvinte fiel pode ser definido como sendo um seguidor da emissora, aquela pessoa que acompanha parte ou toda a programação, sabe os nomes dos comunicadores, conhece os horários dos programas, participa com sugestões e até com críticas e sente-se, de alguma forma, parte da vida da rádio. Além disso, recusa-se a ouvir qualquer outra emissora que não seja aquela da sua preferência absoluta. O ouvinte fiel faz ainda propaganda da rádio e induz outras pessoas a também fazerem parte do público cativo. Alguns ouvintes fiéis tornam-se tão intimos da emissora e de seus funcionários que levam presentes, sabem as datas de aniversário, enviam cumprimentos em ocasiões festivas e visitam a rádio de vez em quando, além de manter contato constante por telefone, por cartas elou e-mail ${ }^{5}$."

(Prata, 2003, p. 139)

Usando como referência os relatórios do Instituto Brasileiro de Opinião Pública e Estatística referentes ao mercado de Belo Horizonte, Prata (2013, p. 136-8) procura caracterizar as emissoras com alto índice de fidelidade. Neste sentido, observa que possuem maior tendência à audiência exclusiva emissoras: (1) voltadas para um público mais adulto e, portanto, menos afeito a alterações constantes, ao contrário do jovem, tipo de audiência com tendência maior à busca daquilo que pode ser considerado diferente; (2) altamente segmentadas com foco em um público específico, resultado do próprio processo de parcelamento da audiência pela emissora; (3) que mantêm os mesmos programas durante anos, permitindo aos ouvintes acostumarem-se com 
comunicadores, formatos, horários e tipos de atrações, conjunto de fatores a marcar o cotidiano desta audiência; e (4) evangélicas, pela associação da rádio à fé professada pelo público.

Já Morgado (27 set. 2011) considera que "as emissoras promovem e vendem relacionamentos - seja entre pessoas, seja entre pessoas e empresas", os quais são mediados por valores transmitidos, no caso das rádios, por meio da marca destas. A respeito, o consultor exemplifica em outro artigo:

Todos os grandes grupos de comunicação do mundo já atentaram para isso e estão trabalhando suas estações como marcas que promovem uma nova gama de relacionamentos e formas de transmissão de conteúdo que vão além, inclusive, da própria programação e se transformam, por exemplo, em eventos, mensagens de texto para celular, colunas em jornais, portais na internet e até programas de TV, sendo tudo sustentado por grifes multimídias que nasceram no rádio e que, de tão fortes, expandiram suas fronteiras de atuação."

(Morgado, 29 mar. 2011)

Problematizada a questão da comunidade de ouvinte, tem-se os elementos necessários para a análise do negócio representado pela indústria de rádio, em especial no que diz respeito ao que uma emissora produz e coloca em circulação na sua busca por lucro.

\section{A mercadoria do rádio}

Para a economia política do rádio, portanto, constitui-se em questão transcendente saber qual em realidade é a mercadoria oferecida pelas estações ao se organizarem 
como negócio dentro do sistema capitalista. Trata-se de analisar qual o foco do processo de produção no meio e de se desvelar a quem se destina o resultado deste: aos ouvintes, como querem os mais otimistas, ou - dentro da realização comercial do negócio radiofônico - aos anunciantes, proposição mais afeita às teorizações de cunho crítico. Neste sentido, torna-se essencial compreender as alterações ocorridas ao longo do tempo nas emissoras comerciais e, nestas, a gradativa migração de uma ideia vaga a respeito do público para um contexto orientado por levantamentos de audiência, no qual aparecem, mais recentemente, noções mercadológicas como as já citadas e referentes à fidelização da audiência e à valorização da marca e das possibilidades de relacionamentos gerados por essa.

No campo crítico, uma resposta vem das formulações de Smythe (1983) a respeito da TV. O professor canadense refuta ideias associadas ao conteúdo e expressas em conceitos subjetivos - mensagem, informação, imagem ${ }^{6}$, significado, entretenimento, orientação, educação e manipulação -, defendendo que o público é a forma da mercadoria constituída pelas comunicações produzidas para as massas e financiadas pelos anunciantes:

Que é o que compram os anunciantes com seus gastos em publicidade? Como sólidos homens de negócio, não estão pagando inutilmente pela sua publicidade, nem thes move o altruísmo. Sugiro que o que compram é o serviço de certos públicos, de especificações previsíveis, que haverão de prestar sua atenção em quantidades previsíveis e, em certos momentos, particulares para determinados meios particulares de comunicação (televisão, rádio, jornais, revistas, outdoors, impressos distribuídos pelo correio). Como coletividades, esses públicos são mercadorias. Como tais, são traficados nos mercados por produtores e consumidores (estes últimos são os anunciantes). Tais mercados estabelecem seus preços, no modo habitual do capitalismo monopólico."

(Smythe, 1983, p. 76) 
O autor deixa clara a relação desta proposição com a vigência do capitalismo monopólico, valendo lembrar, portanto, o que esse representa em termos de alterações nas regras de competição empresarial a partir da década de 1970:

O que distingue o capitalismo monopólico do da fase anterior denominado de competitivo ou liberal - é antes de mais nada a mudança nas regras da competição. Nos mercados competitivos, numerosas empresas disputam a preferência dos compradores mediante preços mais baixos ou vantagens análogas, tais como prazos mais longos de pagamento, descontos etc. Nos mercados monopólicos, a preferência dos compradores é disputada por pequeno número de grandes firmas mediante diferenciação dos produtos, prestígio da marca e publicidade. $O$ público consumidor é persuadido de que a marca e a aparência do produto representam qualidade superior e, portanto, justificam o pagamento de um preço mais alto."

(Singer, 1987, p. 75)

No caso brasileiro, como já citado, a impossibilidade de quantificar e qualificar a mercadoria "público" constitui-se em um dos fatores a impossibilitar a ascensão do rádio ao patamar de indústria cultural já nos anos 1950. Em realidade, coincidindo com a passagem ao capitalismo monopólico e com o desenvolvimento dos conglomerados comunicacionais na década de 1970, consolidam-se as pesquisas de audiência realizadas por empresas como o Instituto Brasileiro de Opinião Pública e Estatística (Ibope) e a Marplan - Pesquisas e Estudos de Mercado, atual Ipsos Brasil. As rádios, portanto, geram com sua programação a audiência - mensurada em termos estatísticos 
e especificada quantitativa e qualitativamente -, que é oferecida como mercadoria aos anunciantes. Quanto maior o número de ouvintes aferido e/ou quanto maior o seu poder de consumo em relação a dado produto ou serviço, tanto mais caro custará o espaço comercial disponibilizado.

Sob o pós-fordismo, no entanto, a resposta de Smythe aventa-se, não resolve totalmente a questão. Serve para que se elucide parte do fenômeno representado pelo rádio comercial, o seu lado mais empresa, ou, usando a terminologia de Tönnies (In: Miranda, 1995), o de sociedade, estabelecida sob as bases da reflexão, da conveniência de interesses e de uma construção conceitual. Esta última,advoga-se, é o que, no caso de uma emissora de rádio, recebe o nome de identidade. A respeito, em seu Radio: the book, uma publicação sob a chancela da NationalAssociationofBroadcasters (NAB), querepresenta os empresários do setor nos Estados Unidos, Warren (2005, p. 97) observa em relação à importância dessa para as emissoras comerciais:

Não importa qual o formato, que tipo de música toca, qual a cidade onde está localizada, ou quantos concorrentes possui; a única coisa que é absolutamente necessária ao sucesso como negócio de uma rádio é definir uma identidade para ela. A identidade de uma emissora precisa ser uma combinação de tudo que a rádio representa para os seus ouvintes, sintetizada em um ou dois elementos altamente identificáveis. Uma identidade é a única coisa que, quando as pessoas veem, ouvem ou pensam no nome da emissora, proporciona essencialmente uma imagem instantânea da própria rádio. A identidade da emissora pode ser obtida principalmente por meio do que é oferecido aos ouvintes em termos de programação." 
Do ponto de vista empresarial, uma identidade bem-sucedida está associada à consistência de mensagem em si, de estilos e formas de apresentação e locução, das palavras de ordem e slogans empregados, em resumo, de um conjunto ajustado de elementos que perpassa todas as atividades o tempo todo e é facilmente reconhecido pelo público. É um processo relacionado a dois conceitos, assim definidos por Zozzoli (2010, p. 783): (1) marca, "um elemento identificador e diferenciador, preferencialmente legível, audível, facilmente pronunciável e memoriável, evocador e declinável"; e (2) branding, "o conjunto de atividades que visa à construção e ao fortalecimento de uma marca".

A construção de uma identidade para a emissora - e, no caso desta ser reconhecida pelo público, de seu consequente impacto em termos de conformação de uma comunidade de ouvintes - só é possível porque o rádio como meio e essa estação determinada como veículo constituem-se, como bem coloca Meditsch, em instituições sociais (2001, p. 31-2) ou criações culturais (2010, p. 204) coletivamente constituídas:

Há mais de uma década, começamos a questionar o conceito de rádio atrelado a uma determinada tecnologia, procurando demonstrar que melhor do que isso seria pensar o rádio como uma instituição social, caracterizada por uma determinada proposta de uso social para um conjunto de tecnologias, cristalizada numa instituição. Consideramos hoje melhor ainda pensar esta instituição social como uma criação cultural, com suas leis próprias e sua forma específica de mediação sociotécnica, numa analogia ao que propõe a ciência do jornalismo para definir o jornal. Assim como a existência de um jornal não se restringe ao calhamaço de papel impresso que foi publicado hoje, nem 
ao que foi publicado ontem, mas se vincula a uma ideia objetivada e apoiada numa instituição social, que permeia e supera a edição de cada dia, a existência de uma emissora de rádio em particular, e do rádio em geral como instituição, não pode mais ser atrelada à natureza dos equipamentos de transmissão e recepção utilizados para lhe dar vida, mas sim à especificidade do fluxo sonoro que proporciona e às relações socioculturais que a partir dele se estabelecem."

(Meditsch, 2010, p. 204)

A identidade articula também a fidelização do ouvinte e permite, com isto, a atribuição de valor aos relacionamentos oferecidos pela marca da emissora ou desta associada à do conglomerado midiático controlador da estação de rádio.

\section{Considerações finais}

De novembro de 2013 a janeiro de 2014, as estações mantidas pela Central Brasileira de Notícias nas regiões metropolitanas de São Paulo, Rio de Janeiro e Belo Horizonte, mais o Distrito Federal, atingiram um pico de 122.951 ouvintes por minuto, das 6 às 9h,conforme o Instituto Brasileiro de Opinião Pública e Estatística. Com a convergência tomando o lugar da segmentação na estratégia mercadológica predominante, não apenas este público - em sua maioria, do sexo masculino, das classes A e B, da faixa etária de 25 a 49 anos e com grau de instrução médio ou superior - contribui para a conformação da mercadoria oferecida pela emissora. Em abril de 2014, podcasts de comentaristas como Max Gehringer e Arnaldo Jabor (os dois mais acessados no site desta rede de emissoras) contabilizaram, respectivamente, 30.930 e 28.720 downloads por dia. Mesmo com a variedade de informações disponibilizada pela rádio em seu Mídia kit (CBN, 2014), é difícil precisar até que ponto internautas são atraídos pela 
participação destes profissionais na programação da CBN ou por suas atuações em outros veículos das Organizações Globo. Esta breve descrição serve para ponderar o poder da audiência como mercadoria na cadeia de valor do rádio comercial sob a vigência da fase de convergência.

Constatações como esta começam a tencionar certezas. Podem indicar que a marca, poderoso fator de valorização sob a vigência do capitalismo monopólico, ganha força no rádio expandido. A tornar mais complexo este processo, vale relembrar três considerações a respeito das modalidades hertzianas e on-line de conformação do emissor radiofônico: (1) o rádio via ondas eletromagnéticas e o rádio via rede mundial de computadores, pelo menos neste momento de seus desenvolvimentos históricos, tendem a requerer lógicas de comercialização diversas; (2) na irradiação por antena, o faturamento baseia-se, ainda, principalmente na venda dos índices de audiência deste ou daquele programa, deste ou daquele comunicador; e (3) na transmissão on-line, há, de um lado, a dificuldade para qualificar como produto o público mensurado, por exemplo, na quantidade de acessos ao sinal da emissora ou de downloads de conteúdo radiofônico; e, de outro, diversificam-se as formas de oferta de informações aparentemente gratuitas e construídas, por vezes, de modo colaborativo.

A parte rádio compreendida como empresa não pode ignorar a parte rádio que conforma, de modo simbólico, uma comunidade de ouvintes. Se antes o público era considerado numericamente ou por suas características específicas, tornandose mercadoria na proposição de Smythe (1983), na contemporaneidade, com mais e mais instrumentos a proporcionar algum nível de interação, os quais são apropriados pelas emissoras, a audiência, como observa Prata (2003), precisa, cada vez mais, ser fidelizada e vive sob, na descrição de Morgado (29 mar. 2011/27 set. 2011), intenso foco de promoções, serviços oferecidos e ofertas de conteúdo em outros veículos do mesmo conglomerado. Neste sentido, como elemento unificador a relacionar 
tudo e, inclusive, trazer para um campo comum os anunciantes, aparece a ideia de identidade, posicionando-se para além da marca, manifestação construída empresarialmente da imagem da emissora e/ou do grupo comunicacional do qual esta faz parte.

Talvez fique mais acessível explicar assim: uma rádio pode possuir marca, ter se definido em seu processo de branding, mas se estes não se realizam no campo de experiência comum, necessário à comunicação, não há identidade. Essa última precisa provar para o ouvinte que o comunicador ao microfone, a estação ou o conglomerado comunicacional estão ali, ao lado, posicionados como companheiros de quem recorre a eles. É o momento, pode-se supor, quando a sociedade - a empresa - tende a gerar, obrigatoriamente, em torno de si a sua comunidade virtual de ouvintes.

\section{REFERÊNCIAS}

ADORNO, Theodor Wiesengrund. A indústria cultural. In: COHN, G. (Org.). Comunicação e indústria cultural. 4. ed. São Paulo: Companhia Editora Nacional, 1978. p. 287-295.

ADORNO, Theodor Wiesengrund; HORKHEIMER, Max. Dialética do esclarecimento: fragmentos filosóficos. 2. ed. Rio de Janeiro: Jorge Zahar, 1986.

BRUCK, Mozahir Salomão. Jornalismo radiofônico e vinculação social. São Paulo: Annablume, 2003.

CENTRAL BRASILEIRA DE NOTÍCIAS. Mídia kit. São Paulo, 2014. Disponível em: <http:// www.sgr.com.br/ web/midiakit/con-midia-kit.aspx?>. Acesso em: 7 maio 2014.

FERRARETTO, Luiz Artur. Rádio e capitalismo no Brasil: uma abordagem histórica. In: HAUSSEN, Doris Fagundes; BRITTOS, Valério Cruz (Org.). Economia política, comunicação e cultura: aportes teóricos e temas emergentes na agenda política brasileira. Porto Alegre: Editora da PUCRS, 2009. p. 93-112. (Coleção Comunicação, 45).

. Uma proposta de periodização para a história do rádio no Brasil. Eptic - Revista de Economia Política das Tecnologias da Informação e Comunicação, Aracaju: Observatório de Economia e Comunicação da Universidade Federal de Sergipe, v. XIV, n. 2, maio-ago. 2012. Disponível em: <http://www.seer.ufs.br/index.php/eptic/ article/viewFile/418/332>. Acesso em : 10 maio 2014. 
FERRARETTO, Luiz Artur. A reconfiguração do rádio como negócio: reflexões a respeito das emissoras online. In: LOPES, Ruy Sardinha; BRITTOS, Valério Cruz (Org.). Políticas de comunicação e sociedade. São Paulo: Intercom, 2012. p. 195-221. (Coleção GPs, 2). Disponível em: <http://inter-com.org.br/e-book/colecao-gps-2.pdf>. Acesso em: 20 abr. 2014.

. O de lá e o de cá: apontamentos para uma categorização do conteúdo das emissoras comerciais brasileiras com base na influência do rádio dos Estados Unidos. Significação - Revista de Cultura Audiovisual, São Paulo: Universidade de São Paulo, ano 40, n. 39, jan.-jun. 2013, p. 44-79. Disponível em: <http://www. usp.br/significacao/pdf/Significacao39_4.pdf>. Acesso em: 01 jan. 2014.

. Da segmentação à convergência, apontamentos a respeito do papel do comunicador de rádio. In: Congresso Brasileiro de Ciências da Comunicação, 36., 2013, Manaus. Anais... Manaus: Sociedade Brasileira de Estudos Interdisciplinares da Comunicação, 2013. CD-ROM.

FERRARETTO, Luiz Artur; KISCHINHEVSKY, Marcelo. Rádio e convergência: uma abordagem pela economia política da comunicação. Revista Famecos, Porto Alegre: Pontifícia Universidade Católica do Rio Grande do Sul, v. 17, n. 3, p. 172-180, set.-dez. 2010. Disponível em: <http://revistasele-tronicas.pucrs.br/ojs/index.php/ revistafamecos/article/view/8185/5873>. Acesso em: 30 dez. 2013.

KISCHINHEVSKY, Marcelo.Rádio social: mapeando novas práticas interacionais sonoras. Revista Famecos, Porto Alegre: Pontifícia Universidade Católica do Rio Grande do Sul, v. 19, n. 2, p. 410-437, maio-ago. 2012.

MATTELART, Armand; MATTELART, Michèle. Historia de las teorías de la comunicación. Barcelona: Paidós, 1997. (Paidós Comunicación, 91).

MEDITSCH, Eduardo. O rádio na era da informação: teoria e técnica do novo radiojornalismo. Florianópolis: Insular/Editora da UFSC, 2001.

. A informação sonora na webmergência: sobre as possibilidades de um radiojornalismo digital na mídia e pós-mídia. In: MAGNONI, Antônio Francisco; CARVALHO, Juliano Maurício de (Org.). O novo rádio: cenários da radiodifusão na era digital. São Paulo: Senac, 2010. p. 203-238.

MEYROWITZ, Joshua. No sense of place: the impact of electronic media on social behavior. Nova Iorque: Oxford University Press, 1989.

MIRANDA, Orlando de (Org.). Para ler Ferdinand Tönnies. São Paulo: Editora da USP, 1995.

MORGADO, Fernando. O futuro do rádio. Observatório de Imprensa. São Paulo: Instituto para o Desenvolvimento do Jornalismo, 29 mar. 2011. Disponível em: <http://www.observatorioda-imprensa.com. br/news/view/o_futuro_do_radio>. Acesso em: 13 abr. 2014.

. A terceira era do rádio e da TV. Observatório de Imprensa. São Paulo: Instituto para o Desenvolvimento do Jornalismo, 27 set. 2011. Disponível em: <http://www.observatoriodaim-prensa.com.br/news/view/_a_ terceira_era_do_radio_e_da_tv>. Acesso em: 13 abr. 2014. 
NASCENTES, Antenor. Dicionário de sinônimos. 3. ed. Rio de Janeiro: Nova Fronteira, 1981.

ORTIZ, Renato. A moderna tradição brasileira: cultura brasileira e indústria cultural. 5. ed. São Paulo: Brasiliense, 1994.

PAIVA, Vanessa. Uma comunidade de ouvintes: a sociabilidade proporcionada pelo rádio. Geraes - Estudos em Comunicação e Sociabilidade, Belo Horizonte: Universidade Federal de Minas Gerais, n. 47, 1. sem. 1995.

PRATA, Nair. A fidelidade do ouvinte de rádio. Conexão, Caxias do Sul: Editora da UCS, v. 2, n. 3, p. 133-147, 2003.

RICHERS, Raimar. Segmentação de Mercado: uma visão de conjunto. In: RICHERS, Raimar; LIMA, Cecília P. (Org.). Segmentação: opções estratégicas para o mercado brasileiro. São Paulo: Nobel, 1991. p. 13-24.

SINGER, Paul. O capitalismo: sua evolução, sua lógica e sua dinâmica. 5. ed. São Paulo: Moderna, 1987.

SMYTHE, Dallas. Las comunicaciones: agujero negro del marxismo occidental. In: RICHERI, Giuseppe (Org.). La televisión: entre servicio público y negocio. México: Gustavo Gili, 1983. p. 71-103.

WARREN, Steve. Radio: the book. For creative professional programming. 4. ed. Burlington (Massachusetts): Focal Press, 2005.

ZOZZOLI, Jean-Charles Jacques. Marca. In: ENCICLOPÉDIA INTERCOM DE COMUNICAÇÃO. São Paulo: Sociedade Brasileira de Estudos Interdisciplinares da Comunicação, 2010. v. 1, p. 781-784. (Dicionário Brasileiro do Conhecimento Comunicacional). CD-ROM.

\section{NOTAS}

1 Versão de artigo apresentado no Grupo de Pesquisa Rádio e Mídia Sonora, dentro do XIV Encontro dos Grupos de Pesquisa em Comunicação, evento componente do XXXVII Congresso Brasileiro de Ciências da Comunicação, realizado em Foz do Iguaçu, no mês de setembro de 2014.

2 Considerando a internet como a gigantesca rede de aparatos conectados para a troca de informações e a web como uma das formas em que ocorrem estes intercâmbios - um ambiente de disponibilização de conteúdo -, talvez fosse mais abrangente utilizar a expressão rádio na internet. No entanto, optou-se por rádio na web, buscando, obviamente, a oposição à web rádio.

3 A expressão "comunidade de ouvintes", mesmo que amparada em bases teóricas diversas, aparece também, com sentido semelhante ao aqui pretendido, em trabalhos de outros autores, entre eles, Vanessa Paiva (1995).

4 Trata-se de A fidelidade do ouvinte de rádio: um estudo dos fatores determinantes da audiênciafiel, defendida na Universidade São Marcos, de São Paulo, no ano 2000, origem do artigo utilizado como referência. 
5 Obviamente, acrescentam-se, nesta relação, formas de contato posteriores à produção do texto, como as proporcionadas pelas redes sociais.

6 Como Dallas Smythe analisa a televisão, este termo refere-se ao aspecto visual e não à sua acepção mercadológica.

Recebido em: 05 out. 2014

Aceito em: 07 nov. 2014

\section{Endereço do autor:}

Luiz Artur Ferraretto <luiz.ferraretto@uol.com.br>

Departamento de Comunicação - UFRGS

Rua Ramiro Barcelos 2705 - 2o andar - Santana

90035-007 Porto Alegre, RS, Brasil

Tel.: (51) 3308-5116 